\title{
HERITAGE ARCHITECTURE IN IBADAN, NIGERIA: THE HOUSE OF ADEBISI GIWA OF IDIKAN
}

\author{
Adeoye Dorcas Oluwaseyi ${ }^{\star 凶}$, Akande Adeyemi and Oladiti Abiodun Akeem \\ ${ }^{1}$ Department of Architecture, Ladoke Akintola University of Technology, Nigeria \\ ${ }^{2}$ Department of Architecture, University of Lagos, Akoka, Lagos, Nigeria \\ 3Department of General Studies, Ladoke Akintola University of Technology, Nigeria
}

\begin{abstract}
Original Article
ABSTRACT

This paper examines the architectural design and planning of the residential apartment of the great Ibadan icon, businessman and philanthropist. The architecture is neo-classical and the building boasts of at least eighty five living

PII: S238315531800002-7 spaces (parlour and rooms). The Adebisi mansion is a symbol of Ibadan-Yoruba material heritage. The people of Ibadan had great respect for the patron of the house - Giwa Adebisi and this is confirmed in the fact that his memories are preserved in legend, songs and poems that enunciate the man's wealth and influence. These legends and songs that accompany his home in Ibadan is rarely found elsewhere in Yoruba society. The paper discusses the grandeur of the Adebisi mansion and concludes that the building is of significant historic and architectural heritage value and thus makes a worthy material for preservation.

Corresponding author's e-mail:
\end{abstract} aaoladiti@lautech.edu.ng

\section{KEYWORDS}

Heritage, Architecture, Colonial, Patronage, Ibadan.

\section{INTRODUCTION}

"Eni ti o ba fe ko iru ile Adebisi, ko ni ile ko"

"One who seeks to build a house like Adebisi, is not ready to build a house".

The aforementioned maxim in the Yoruba repertoire is a popular saying in Ibadan in the $20^{\text {th }}$ century. It was used to advise young people not to nurture the desire to build a house like Adebisi's mansion as it will be futile. The mansion of Adebisi has been portrayed in the Ibadan worldview as a structure like the Mapo hall in grandeur, elegance and splendor. The prevalent belief at the time the structure was built was that materials for the construction of the building could only have come from Europe. The construction of the building started in 1927 and was completed before the commissioning of Mapo Hall in October 5, 1929 [1]. The idea behind heritage Architecture which is primarily concerned with structures or parts of structure which carry a historical value often in the context of its host culture or society helps us put this study of the Adebisi mansion in perspective. The study helps us demonstrate and appreciate the importance attached to the brilliance of human creativity as expressed in built form. Architectural heritage embodies the outstanding artistic and historic value of a monument while manifesting human ingenuity [2]. This paper advances the functional use of space as a creative material culture independent from colonial finance, maintenance or repairs. The building symbolizes the wealth of Adebisi as cultural metaphor and a significant historical connotation for the Oyo Yoruba groups in Southwest Nigeria. It emphasizes the phenomenal position of the built environment in the architectural development of Ibadan society.

\section{Sanusi Adebisi Giwa of Idikan}

An Ibadan native, Sanusi Adebisi Giwawas a prominent businessman in Ibadan in the first half of the twentieth century. Owing to the sketchy and uncoordinated process of formal registration of birth in the late nineteenth century in western Nigeria, Sanuni's exact date of birth is unknown but he is believed to have been born around early-189os. Historian professor Adesina describe him as a hard driven entrepreneur in the Ibadan cocoa business scene. The story of his childhood is scanty but research shows that as a youth, he was involved in his father's business enterprise which was basically the marketing of traditional textiles -Adire and AsoOke. He hawked from one Yoruba town to another 
and this provided an outlet of his spirit of enterprise and ingenuity in the field of business [3].

Adebisi rose to a position of respect and honor among his peers due to his success and achievements. On account of this achievements, legends, songs, and poems that celebrated his popularity, wealth and influence played a significant role in immortalizing him as a great Ibadan entrepreneur. Further to this, and possibly more significantly, his famous residential building known as "Ile Adebisi Giwa of Idikan" made him a household name all through Ibadan city. The structure is indeed a worthy architecture icon and material heritage for coming generations.

A vivid illustration of the eminence the building carries among the Ibadan people is captured in the Yoruba poem documented by Odunjo and used in the teaching of Yoruba literature among the primary school students in western Nigeria. The poem titled "owo Apekanuko" celebrated Adebisi thus:

"osi nii je ta ni-mo-o ri

Se owo lo nje mo-ba-o-tan

Buroda idi-kan

L'owo so Adebisi

Gbogbo aye nii d'ebi

Eni owo ba n baje."

"Poverty brings about who are who?

Money (wealth) brings about I'm your kindred

Brother at Idi-kan

Is what money made Adebisi

Everyone becomes a relation

Of whosoever swims in prosperity (Odunjo, 2010)" [4].

This poem has become legendary as it accompanies Adebisi's name and is rarely found elsewhere in Yoruba land. The wealth, fame and prestige acquired by Adebisi made him a respected individual that everyone wishes to identify with and refer to as "my brother" who reside at Idi-Kan - the place in Ibadan where the mansion built. The design plan of Adebisi's mansion is quintessential and representative of the emergence of modernist Architecture in colonial Ibadan city.

\section{The architects/ builders of the building}

The Adebisi building was designed and constructed by a Scottish Engineer Robert Taffy Jones, (1882-1949). Taffy Jones supervised the construction of the structure in conjunction with other local professional builders like Engineer Carew, all working as a consortium [5]. Mr Robert
Taffy Jones was the first Ibadan colonial engineer, who worked in Southern Nigeria between 1910-1944 [6]. He started work as a road foreman and was later appointed Engineer to the Ibadan native authority in 1923 [7]. He remained in the ancient city of Ibadan until his retirement and return to Wales in Scotland. $\mathrm{He}$ is reputed to be among the leading engineers in the colonial service of the mid twentieth century. His architectural works presented mostly in neo-classical style were pronounced, brutish but often off tangent with the local urban character and usual Yoruba cluster of twentieth century Ibadan. On the road infrastructural end, Taffy's construction were often commissioned and financed by colonial government in Ibadan [8]. He obtains the agreement of the local community for the necessary demolition of obstruction that affected road construction in the city. His legacy in Ibadan is not easy to occlude. Taffy is responsible for the wide main artery road through the heart of Ibadan (known as Taffy highway). He also designed and constructed the Ibadan town hall at Mapo and the Bower's Tower at Oke Are Hill near Sapati area of Ibadan. This tower is also known as Layipo among the local people. The monument was erected to immortalize the first Resident and Travelling commissioner for the interior of Yoruba land, Captain Robert Lister Bower, who served 1893-1897 [6].

The tower is $60 \mathrm{ft}$. high with an $11 \mathrm{ft}$. square base and two entrances. It also has a 45 double spiral stair case which gave it the name Layipo -- which means meaning spinning around -- amongst the natives. This monumental project was financed by the Ibadan native authority in memory of Sir Robert Lister Bower, K.B.E., C.M.E, and first Colonial Resident of Ibadan 1893-1897 whose character, courage and administrative ability won the universal and lasting esteem of the Yoruba. During his time, he firmly established the loyalty of the people to the imperial crown [6].

At the time Robert Taffy Jones was supervising and constructing the Mapo hall, he was commissioned by Sanusi Adebisi Giwa to design an architectural masterpiece closely related but not necessarily similar to the Mapo Hall that he, at that time was working as site engineer [1].

The building of Sanusi Adebisi Giwa was rated as one of the prominent structures that prides the development of the city of Ibadan and the place called Idi-Kan in particular. The grandeur of the structure was one of its kind and such that was not to be seen in Ibadan or elsewhere in Yoruba society
Citation: Oluwaseyi A.D., Akande A. and Akeem O.A (2018). Heritage architecture in Ibadan, Nigeria: the house of Adebisi Giwa of Idikan. J Art Arch Stud. 7 (1): 11-20.

DOI: https://dx.doi.org/10.51148/jaas.2018.2
Journal of Art and Architecture Studies ISSN: 2383-1553 
during colonial times. The building takes on a dual role of residence and court in the manner that contest with the loftiest abodes of Ibadan royals. Many Ibadan indigenes derived pleasure in the use of the building for social, political and economic interactions within the city. The building has an inspiring influence towards higher ideals in the city's development and broadened their outlook by given them a taste for finer things (Figures 1, 2 and 3).

\section{METHODOLOGY}

The study adopted a historical approach by examining the monumental and popular historic buildings designed by a British engineer in colonial Ibadan city in the first half of the $2 \mathrm{O}^{\text {th }}$ century.

The data for the study were obtained through direct observation, oral interviews with families and relatives to the owner of the building as well as information from books and journal articles related to the study. Photographs of the building were taken by the authors after obtaining permission and acceptance of the occupants living in the residential apartment. The sketch plan of the building provides the background plan of the building.

\section{Description of the Building: Building materials, techniques and construction of Ile-Adebisi Giwa of Idikan walls.}

The sandcrete wall of the building was finish with cement mortar and concrete blocks (Figure 4). With this technique and materials, the Adebisi house accommodated vernacular building practice. What is more concerting is in spite of the unapologetic neoclassical exuberance, the structure remains faithful in philosophy to the use of materials that are in synchrony with traditional Yoruba building ideology.

1) Doors and windows: Doors were made from timber typical of Yoruba traditional houses and windows are made up of glass materials with timber frames in order to admit light into the inside of the building from the outer surroundings or from the courtyard. The main buildings have large glass windows while the bungalows have wooden boards as windows. In fact, in some living and sleeping areas, the windows were so small admitting little light through the outside rather reminiscent of early traditional Yoruba building conceptions.

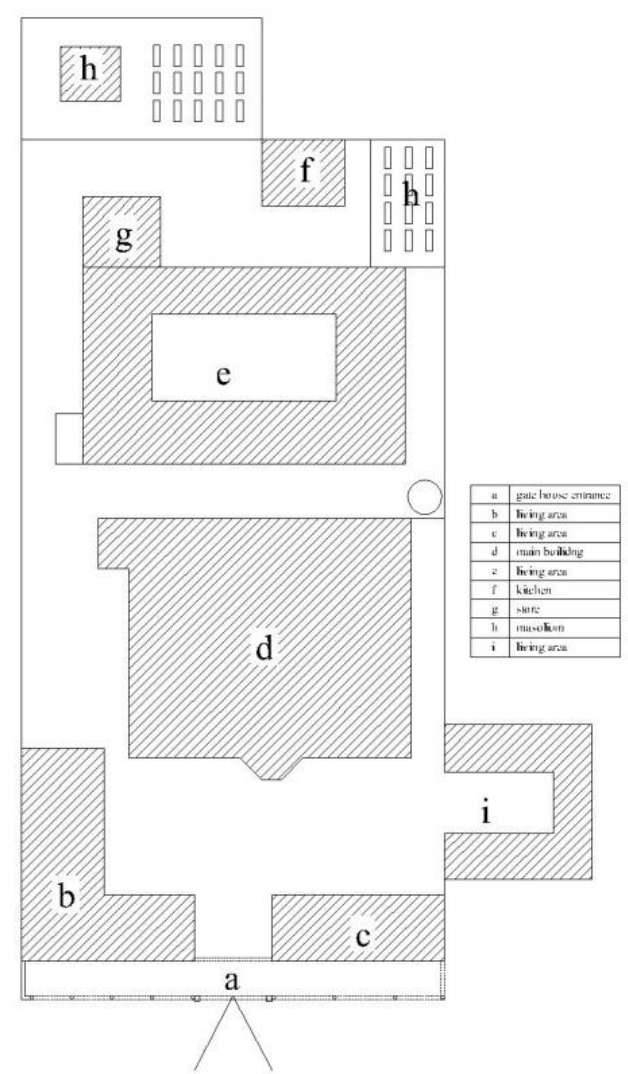

Figure 1: Site Layout.

a. Entrance façade; b. Living area 1 ; c. Living area 2; d. Main Building; e. Living area 3 (children and wives); f. Kitchen; g. Store; h. Burial area (Cemetery/mausoleum); i. Extended family living area (Source: Authors' Survey, 2017).

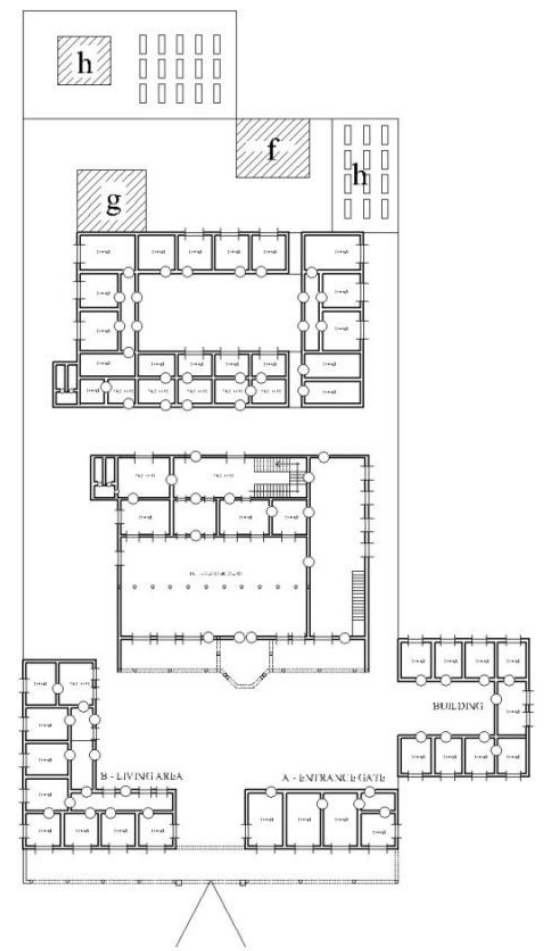

Figure 2: Ground Floor Plans.
Citation: Oluwaseyi A.D., Akande A. and Akeem O.A. (2018). Heritage architecture in Ibadan, Nigeria: the house of Adebisi Giwa of Idikan. J Art Arch Stud. 7 (1): 11-20.

DOI: https://dx.doi.org/10.51148/jaas.2018.2
Journal of Art and Architecture Studies ISSN: 2383-1553 


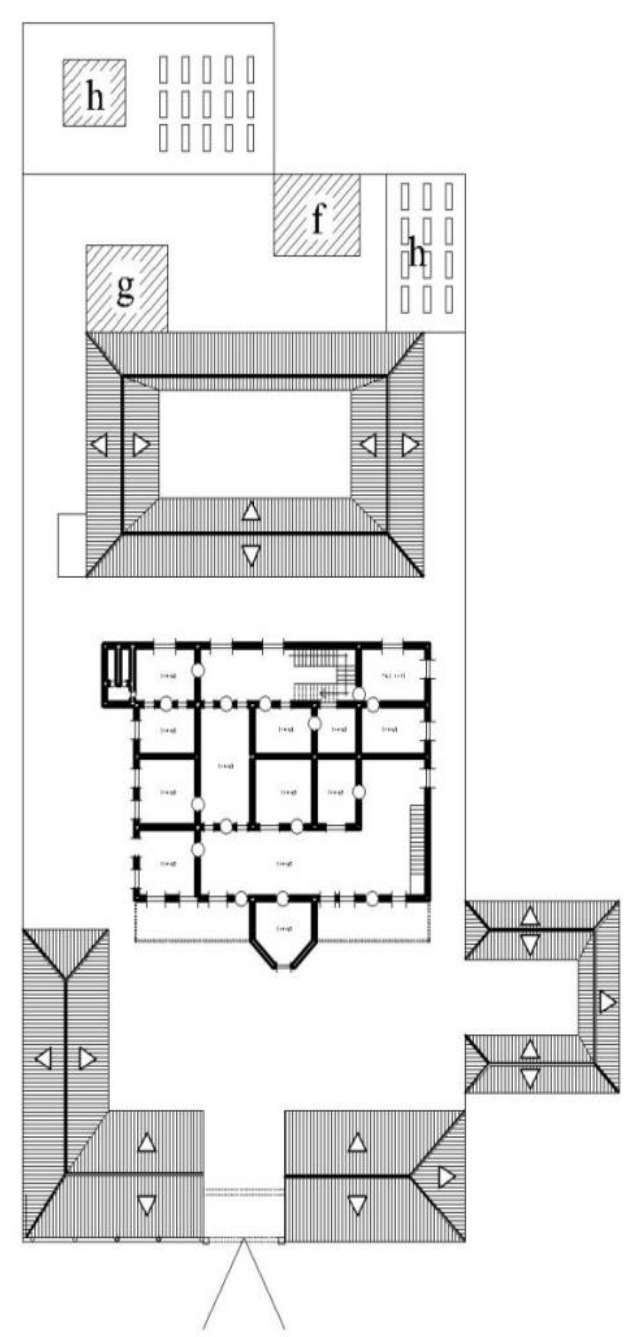

Figure 3: Upper Floor, and roof Plans.

2) Roofs: The main building and the adjoining living areas were roofed with corrugated iron sheets draining into a roof gutter and connected with pipes to drain of the run-off from the hipped end roof. The roof of the main building and the adjoining living areas to the main entrance of the compound were also finished with concrete facial round the total perimeter of the building (Figures 3 and 5).

3) Fencing: The fencing of Adebisi house was well articulated to delimit the property from other structures. The fencing was done in such a way that different flanges between wings of the property were well differentiated from the main building. For instance, the wing housing the parents and other extended family were fenced off from the main building premises but was connected with a gate entrance to accommodate them too (Figure 6). The space left out (at the rear end of the compound) for burial of the dead was also fenced off from the main compound.

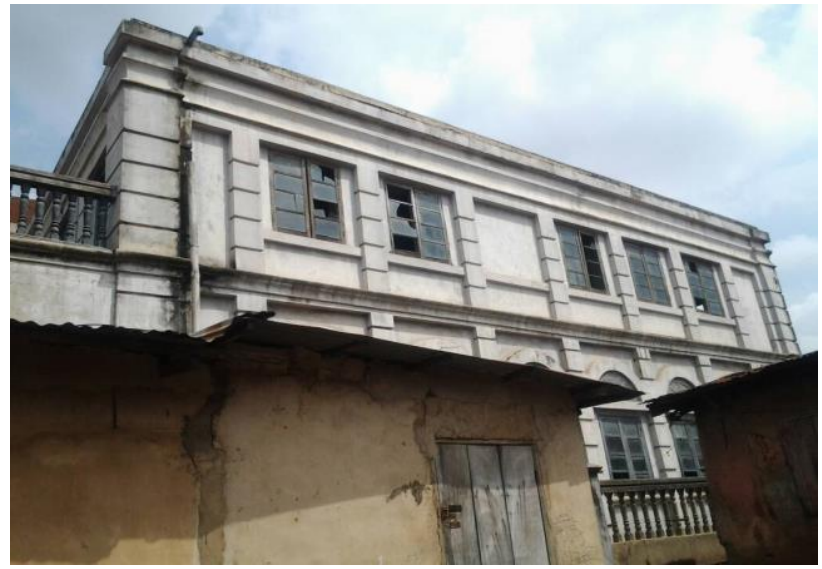

Figure 4: Side view of the building

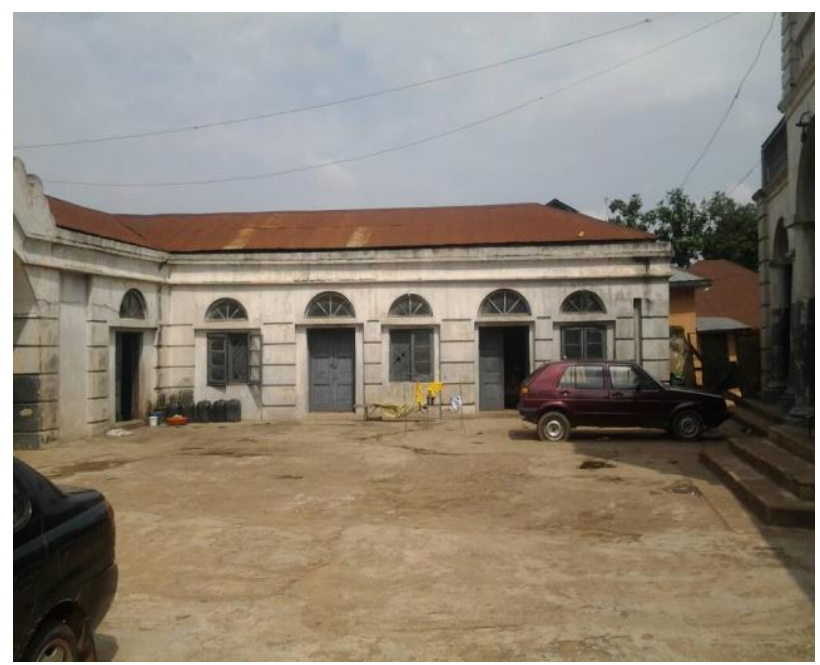

Figure 5: Extended Family house

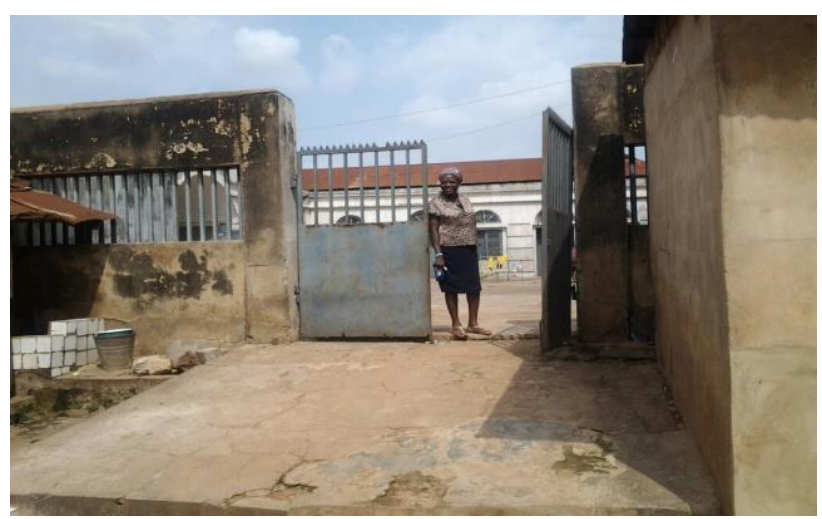

Figure 6: Entrance gate to the extended family area

\section{RESULTS AND DISCUSSION}

The Adebisi Sanusi mansion in Idikan has been described by Ibadan locals as parallel to no other building owned by an individual under colonial rule 
in Western Nigeria. The house was indeed a symbolic creative form of art and architectural master piece of its time. The planning and architectural design of the building was a product of colonialist ideology distilled in modernity. The architecture of the building was articulated in a careful mix of neo-classical and Afro- Brazilian style. Both the western and eastern entrance of the building features a $19^{\text {th }}$ century Portuguese style curved pediment. The eastern end features a remarkably simple low bas relief rendition of a flower on the frontal end. The main approach view of the building is symmetrical and formal in appearance.

The arch curvature at the entrance is supported by two square base columns to each side of the entrance gate. The curved pediment on top of the western entrance is also engraved but this side features an elephant motif with a squirrels placed on either side in an arrangement style that mimics the medieval western European crests. The pediment is further decorated with a flower verse and the inscription "SAG" which stands for Sanusi Adebisi Giwa, the patron of the building (Figure 7).

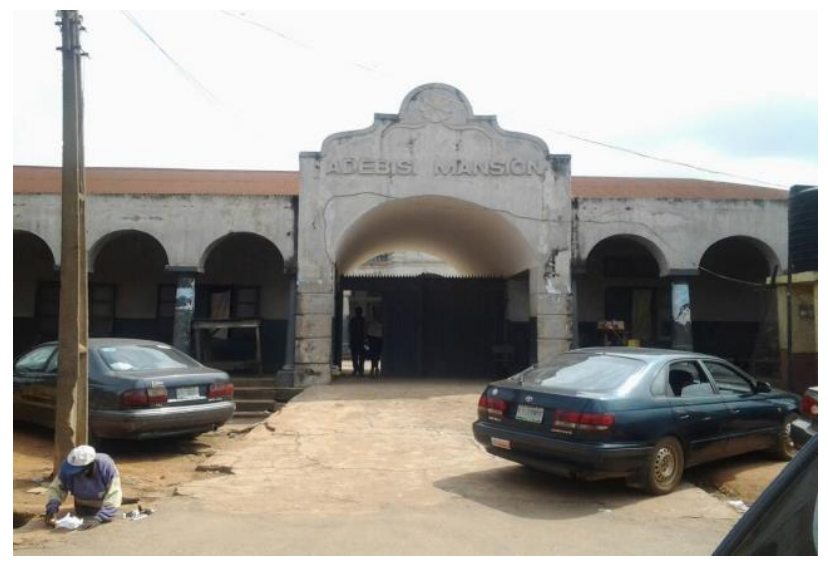

Figure 7: Entrance gate to the building (the elevation rests on an imposing column signifying the strength, power and quality of the building).

\section{Architectural design and planning of the building}

The built area of the Idi-Kan house of Adebisi seats on about a half-acre ( 3 and 1/2 plots) parcel of land. The house comprises of about 85 rooms on two floors of four separate structures with adjourning bungalows providing shelter for other members of the family (Figures 1,2 and 3). Made entirely of sandcrete walls and floors, the structure features typical modern fitted doors and windows made from timber/wood and glass. Reputed to be about ninety years old, it is now mostly in a state of disrepair. That notwithstanding, the building still carries an aura of brilliance and it is still occupied by the members of the Adebisi's family.

Symmetry was a design ideology in the conceptualization of this structure. This is evident in the careful arrangement of the Doric style columns on the approach elevation. Each arch lands on Doric columns and are distributed at equal distance from each other. The central arch which hosts the pediment is flanked by three columns each to both sides (Figure 9) emphasizing balance in the arrangements and forms, a key aesthetic character of the building. The deliberate use of sturdy Doric columns further enunciates rigidity, power and influence; all hallmarks of the patron Adebisi. Though on a minuscule scale, the balustrade on the first floor of the building gives balance and verticality to the otherwise sturdy character of the ground floor.

The central arch which doubles as the entrance porch leads to a big hall (Igbejo) (Figure 10) which is about $86.4 \mathrm{~m}^{2}$ in size and serves as visitor's waiting area and the patron's court used for general family meetings and disputes resolution for neighbours and family members alike. In addition to the court, the ground floor of the main building also consists of a large living room and five adjourning bedrooms. The ceiling of the hall was made of a wooden slab supported by arch curvatures of 10 columns doubling as support for the upper floor slab. The columns serve as the main structural support to the upper floor slab (Figures 8, 9 and 10).

The ground floor of the hall was finished with PVC tiles with wooden skirting round the wall edges to make a neat and well-finished edge. The enclosed walls were finished with glossy paint while the windows are of well-designed wooden net/blind and glass windows (Figures 11 and 13).

It is however clear that the oil paint on the wall now is not the same that was used at inception. It is not uncommon in the western part of current Nigeria for wealthy patrons to repaint their houses yearly in some type of renewal ritual and also as a show of continued affluence and relevance. The ceiling was finished with well-seasoned timber laid in layers and painted in white colour though in dilapidating state now (Figure 12).

The Igbejo hall (Figure 10) on the ground floor also leads to a central lobby which in turn continues to other four adjoining bedrooms and a private 
apartment with a living room and two bedrooms. The private apartment can be accessed via a separate lobby which also provides access to a stair well. The left wing of the hall leads to a stair hall doubling as corridor leading to other parts of the compound. The stair is made of concrete at the lower part (about 10 risers and 9 goings) while the rest (upper) part was made up of timber with wooding balustrades (Figures 14 and 15).

The upper part of the staircase is protected with a wooden door providing security to upper parts of the main building (Figures 15 and 16). The rear part of the building features another stair hall leading to the upper part of the building from the rear which houses the Chief's big private sitting room and his personal bedroom with other bedrooms (about five) used for special guests as the need arose.

The upper floor consists of a long (wide) terrace (Figure 17) in the exterior with wooden balusters/ handrails round the terrace with a pronounced centrally positioned pediment at the top of the main facade finished with the earlier described elephant motif flanked two squirrels showing purposeful ornamentation, a composite order of classical architecture (Figure 17). The pronounced enclosure serves as bedroom for one of Chief Adebisi's sons.

The adjoining two other structures at the back of the main building is famed to house the 36 wives of Chief Sanusi Adebisi Giwa and his children. The other structure adjacent to the main building is built in form of a boy's quarters with sitting rooms and adjoining bedrooms while the last structure at the rear was arranged in a row round a central courtyard and also serves as living apartment for the wives of the Chief and other members of the extended family. The rectangular arrangement in courtyard style aids circulation, lighting and ventilations. Towards the rear of the compound is located the central kitchen which is now out of commission. In the early days, it served as the central cook-house were all the main meal of the compound was prepared. Toward the left was an open bathroom located at the very end of the compound.

In the rear portion of the entire structure and compound houses the mausoleum and the cemetery for the dead members of the family. The main mausoleum houses the remains of Chief Adebisi while the rest of the surrounding land is where his late parents, brothers and some wives were interred. This portion of the compound was fenced off from the main compound to give privacy and respect for the dead.

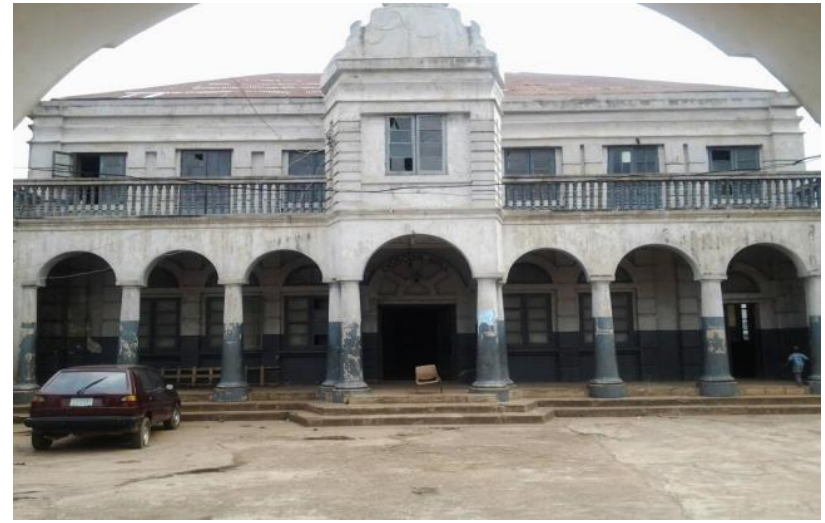

Figure 8: Approach view of the main building

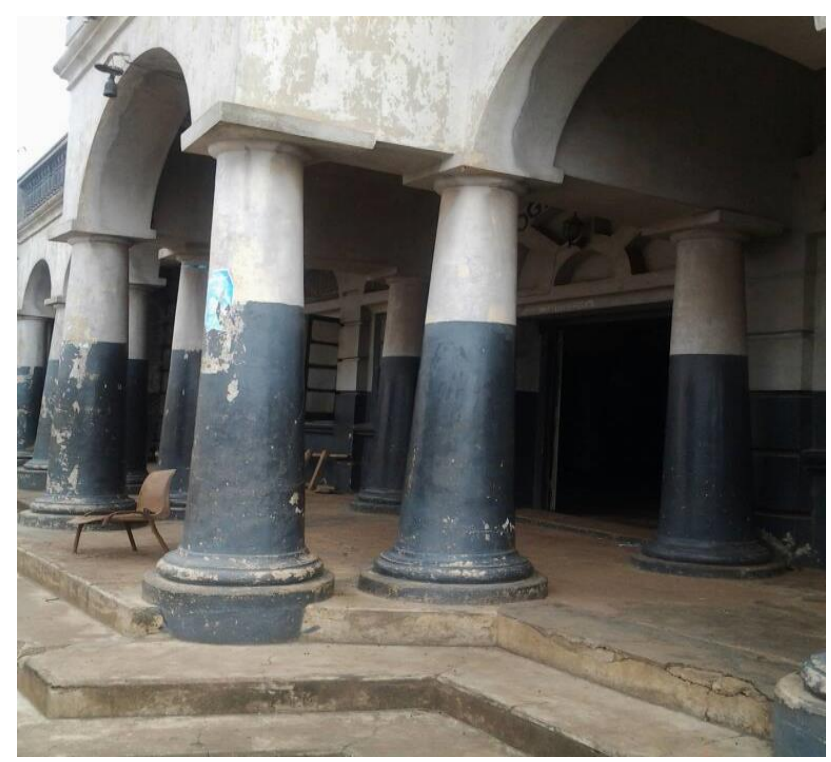

Figure 9: Doric style columns holding the main entrance arches/porch to the building

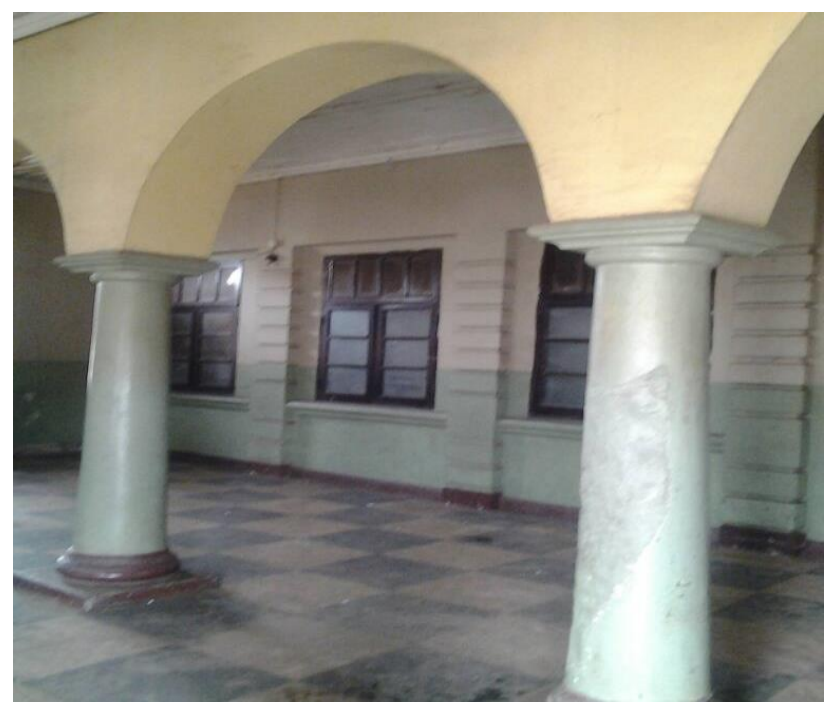

Figure 10: Igbejo Hall
Citation: Oluwaseyi A.D., Akande A. and Akeem O.A (2018). Heritage architecture in Ibadan, Nigeria: the house of Adebisi Giwa of Idikan. J Art Arch Stud. 7 (1): 11-20.

DOI: https://dx.doi.org/10.51148/jaas.2018.2
Journal of Art and Architecture Studies 


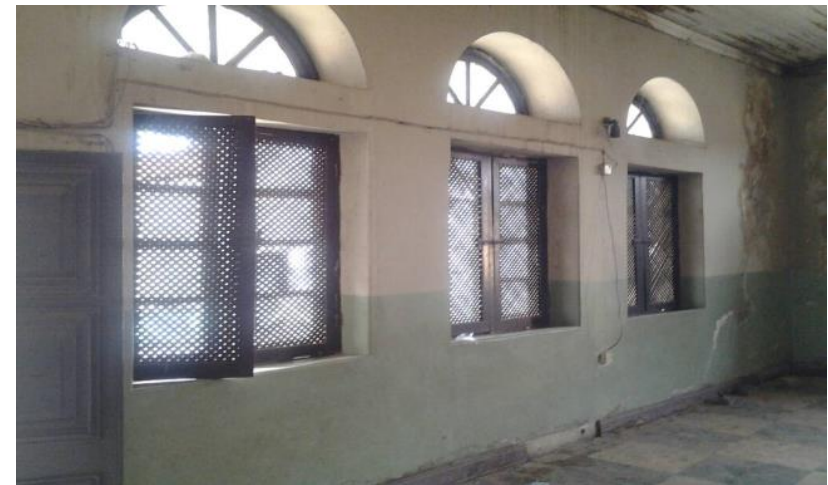

Figure 11: Glass windows with wooden finished blind

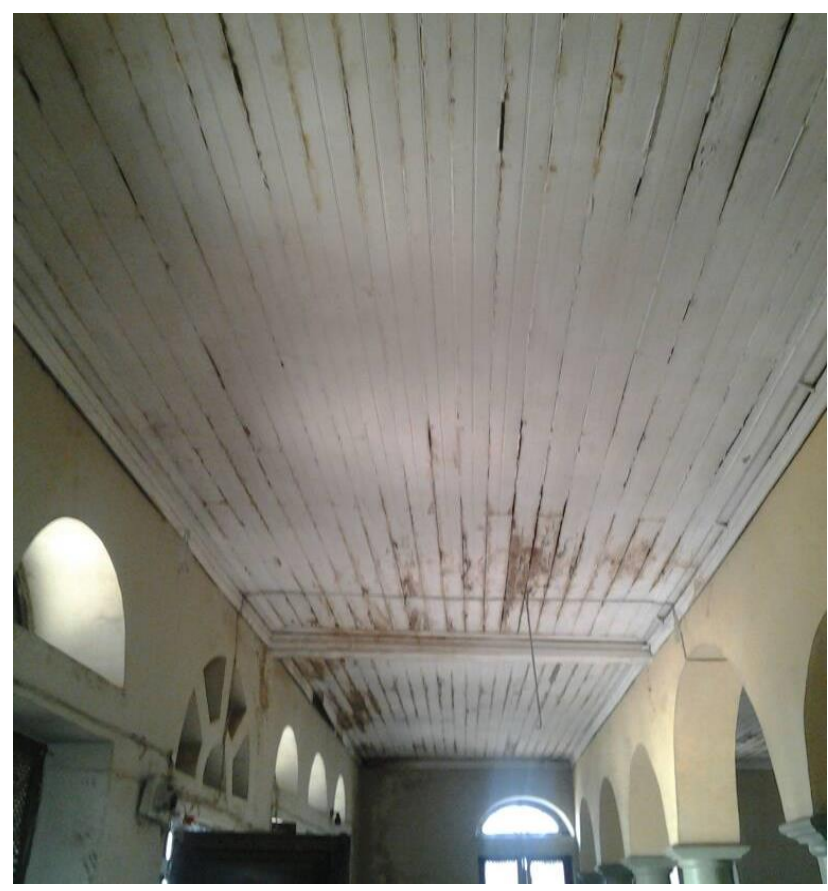

Figure 12: Wooden ceiling in the Igbejo Hall.

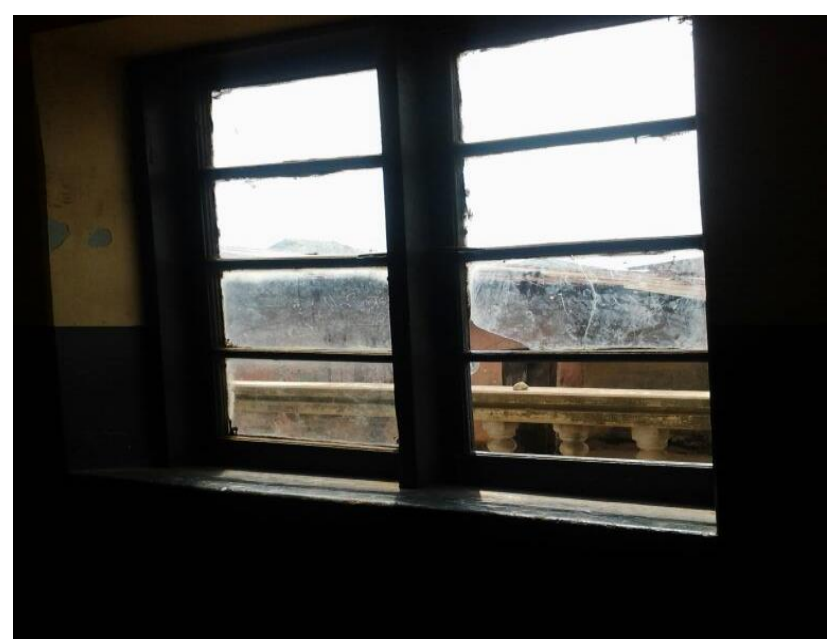

Figure 13: Broken glass window with wooden frames

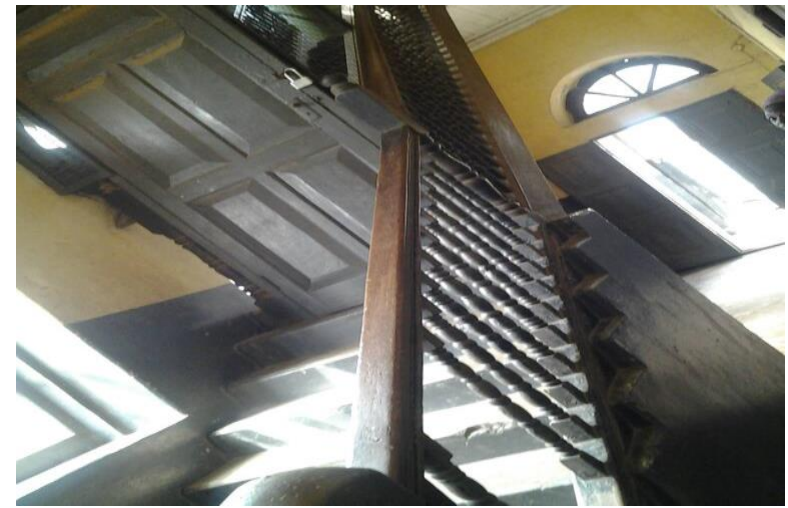

Figure14: Concrete staircase

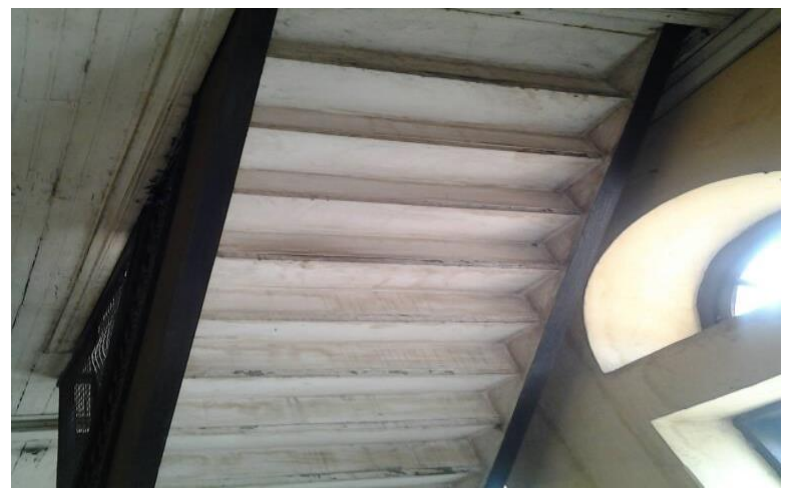

Figure15: Wooden part of the staircase

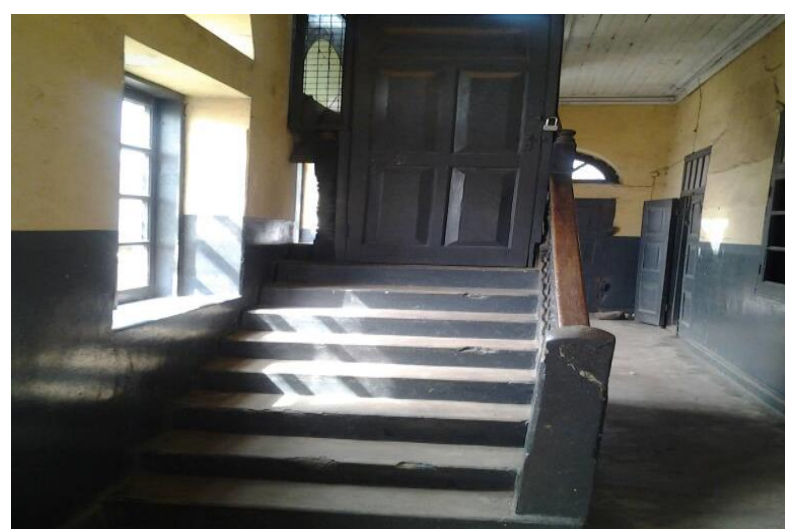

Figure 16: Wooden door used as security to upper start of the staircase

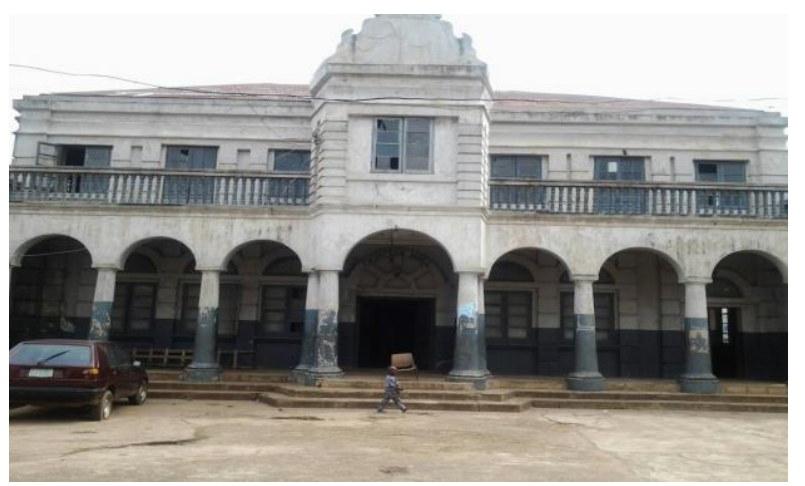

Figure 17: Upper terrace and the elephant motif grounded with squirrels in both sides
Citation: Oluwaseyi A.D., Akande A. and Akeem O.A. (2018). Heritage architecture in Ibadan, Nigeria: the house of Adebisi Giwa of Idikan. J Art Arch Stud. 7 (1) 11-20.

DOI: https://dx.doi.org/10.51148/jaas.2018.2
Journal of Art and Architecture Studies

ISSN: $2383-1553$
Volume 7, No. 1: 11-20.




\section{Design patterns, layout and function of the building}

The primary purpose and typology of the building is residential for the Adebisi family at Idikan, Ibadan. The plans of Adebisi Idikan house as depicted by Figures 1, 2 and 3 showed the compound layout. In figure 1, the site layout is seen showing the Gate house(a) and the adjoining living areas (b \& c), next to it is the main residential building (d) accommodating the chief and some of his guests and grown-up sons. The boys' quarters and the rest living areas (e) house the children and the other wives of the Chief Adebisi. The main significant proportion of the living area in this wing combined the traditional impulvium - courtyard which shows that not only does the design rests on two major neo-classical styles already mentioned, but it also borrows from traditional expressions making it a significant example of hybrid experimentation in colonial western Nigeria. The back of the building contains cooking area-kitchen (f) and the store (g) while the last portion (h) was used as cemetery. The separated living area to the right wing of the compound at the entrance of the compound accommodates the extended family members and Adebisi's parents (Figure 6).

Table 1 below revealed that the building form is rectangular in shape with courtyards showing the characteristics of new-classical and Afro-Brazilians style. The floor finish comprises - polyvinyl chloridetiles while the upper floor (stab) was finished with timber finished. The major function of the floor is to enhance smooth movement of occupants and to prevent moisture and (damp penetration) vegetation growth with the building. Other functions of the floors are to support the occupants to rest their feet and withstand the loads that will be imposed upon it. These loads could be persons, furniture, machines, equipments and book among other.

Table 1. Analysis of the Design Form and Building components of Ile-Adebisi.

\begin{tabular}{|c|c|c|c|c|}
\hline $\begin{array}{l}\text { Generic } \\
\text { structure }\end{array}$ & Type & Material & \multicolumn{2}{|l|}{ Functions usage } \\
\hline Building form & $\begin{array}{l}\text { Rectangular with traditional } \\
\text { courtyard system. Neo- } \\
\text { classical and Afro-Brazillian } \\
\text { style }\end{array}$ & $\begin{array}{l}\text { Purely sancrete and } \\
\text { concrete }\end{array}$ & \multicolumn{2}{|l|}{ Residential Building. } \\
\hline Floor & $\begin{array}{l}\text { Sandcrete, PVC tiles and } \\
\text { timber. }\end{array}$ & $\begin{array}{l}\text { PVC floor tiles, concrete } \\
\text { slab and timber }\end{array}$ & \multicolumn{2}{|c|}{ For resting and smooth movement of occupants. } \\
\hline $\begin{array}{l}\text { Walls and } \\
\text { materials uses }\end{array}$ & $\begin{array}{l}\text { Sandcrete block, concrete } \\
\text { block wall and paint. }\end{array}$ & Cement and sand & \multicolumn{2}{|l|}{ Privacy and protection. } \\
\hline $\begin{array}{l}\text { Door type and } \\
\text { their sizes }\end{array}$ & Wood/ timber & Timber and glass & \multicolumn{2}{|c|}{ Accessibility and circulation movement } \\
\hline $\begin{array}{l}\text { Window type and } \\
\text { floor sizes }\end{array}$ & Wood/ timber and glass & Timber and glass & \multicolumn{2}{|c|}{ Lighting and ventilation. } \\
\hline $\begin{array}{l}\text { Gates types and } \\
\text { materials }\end{array}$ & Steel grills & Steel & \multicolumn{2}{|l|}{ Security. } \\
\hline Ceilings finishes & $\begin{array}{l}\text { Concrete crete and timber } \\
\text { finish }\end{array}$ & $\begin{array}{l}\text { PVC floor tiles, concrete } \\
\text { slab and timber and paint }\end{array}$ & \multicolumn{2}{|l|}{ Security. } \\
\hline Conveniences & $\begin{array}{l}\text { Water System and pit } \\
\text { latrine }\end{array}$ & $\begin{array}{l}\text { Ceramic and Sandcrete/ } \\
\text { concrete }\end{array}$ & \multicolumn{2}{|c|}{ To easy and making good of the body. } \\
\hline Rooms & About 85 rooms & $\begin{array}{l}\text { Sandcrete block wall and } \\
\text { cement mortar plaster }\end{array}$ & \multicolumn{2}{|c|}{ Sleeping and relaxation. } \\
\hline $\begin{array}{l}\text { Hall type and } \\
\text { functions }\end{array}$ & Igbejo & & $\begin{array}{l}\text { Sandcrete walls, } \\
\text { timber ceiling }\end{array}$ & $\begin{array}{l}\text { For receiving large } \\
\text { visitors, holding of family } \\
\text { meeting and mini-court to } \\
\text { settle disputes among } \\
\text { family and neighbours. }\end{array}$ \\
\hline Roof & \multicolumn{2}{|c|}{$\begin{array}{l}\text { Hip roof and concrete roof slab (roof gutter) / deck and } \\
\text { semi-circular arches. }\end{array}$} & $\begin{array}{l}\text { Corrugated iron } \\
\text { sheets with concrete } \\
\text { facial, concrete roof } \\
\text { slab with gutter. }\end{array}$ & $\begin{array}{l}\text { Security, shield from } \\
\text { weather elements and } \\
\text { protection. }\end{array}$ \\
\hline
\end{tabular}

Source: Authors' analysis and interpretation (2017)

The walls of buildings are basically used to divide and enclose spaces, for protection and privacy. The walls of Adebisi Giwa was made up of sandcrete blocks concrete blocks finished with plaster and rendered with emulsion paints. The walls are also used to divide the buildings in to apartments or
Citation: Oluwaseyi A.D., Akande A. and Akeem O.A (2018). Heritage architecture in Ibadan, Nigeria: the house of Adebisi Giwa of Idikan. J Art Arch Stud. 7 (1): 11-20.

DOI: https://dx.doi.org/10.51148/jaas.2018.2 
rooms and defined the space outside and inside the building structure in terms of fence walls. The walls also provide supports to doctenant kind of loads (dead, life and wind loads). The doors and windows are majority of timber/wood material. The major functions of doors and windows are to act shield or barrier to seeing through, add aesthetics value to the building, and providing lighting and ventilation in a building. The windows are also used to enhance visibility from the building which is reflective in the use of glass with wooden frames a most of the windows in Giwa Adebisi Idikan residential buildings. While windows and doors also emphasis the design of the building, the door also serves as access and easy circulation from spaces to spaces in the building. The roof of a building is the envelop for the entire building. The of the building is Hipped type roof with concrete slab gutters round the four sides of the main building through which the drainage gutter were embedded and water drains off from the roof to the ground surface gutter and channelled out of the building, to the main drainage water channel outside the building. The material for the roof is majorly corrugated iron sheets and concrete slab. The entrance gate was made-up of iron grills (Steel material) and serves as check for visitors, and as a means of security to the whole compound. The gate houses are two in number. The ceiling finishes are made up of timber and concrete slab and serves as security and support to upper floor. It also protects the roof materials/ structures and serves as aesthetical value for the building.

The rooms are about 85 rooms in member and are used for relaxation, sleeping and for private activities. The Hall (Igbejo) is made up of sandcrete walls and timber ceiling materials. It is used for receiving visitors; family members; meetings and mini-court which was used by Adebisi Giwa to settle disputes among family members and neighbours.

The conveniences in the main building (toilets and bathroom) are majorly of water system type while those used by other family members are pit latrines located at the extreme back of the family compound.

\section{CONCLUSION AND RECOMMENDATION}

It has been shown from the foregoing that the building of Sanusi Adebisi Giwa is one of the most symbolic creative architectural landmark in Ibadan in the early twentieth century. The ninety year old building is typified as mixture of Neo-classical and Afro-Brazillian mansion in style, design and outlook with an infusion of traditional elements and philosophy. The house is regarded as one of the most celebrated aspects of the material culture of Ibadan people and it prides itself as one not to be found anywhere else in the Yoruba country. With a proportional mix of colonial influence, AfroBrazilianism and the traditional impluviumcourtyard style, the building has stood the test of time since its completion in 1927 as no major or serious repairs have been carried out on the building. The House of Sanusi Adebisi Giwa of IdiKan is indeed and architectural heritage that carry historical value and must be preserved. The conservation and the preservation of the building by family members welcome a visual relief for passersby, visitors and researchers to the family compound. The continued maintenance of the structure must however receive attention from the heritage agency of the Federal government of Nigeria as in no other building in Ibadan is there to be seen the culmination of a heritage infused together as a symbiotic hybrid as one will see in the Adebisi mansion.

\section{DECLARATIONS}

\section{Authors' Contributions}

Dr A.D. Oluwaseyi is the lead author of the manuscript. She visited the building, conducted oral interviews with the occupants of the building and provided a sketch plan of the building. Dr A. Adeyemi provided the analytical interpretation of the designed plan of the building, the building material and the functional utility of space in the building. Dr O. Abiodun Akeem wrote the section on the biography and discussed the personality of the owner of the house, Chief Sanusi Adebis Giwa of Idikan. All the authors directly participated in the planning, execution and analysis of this study, and have read and approved the final version submitted.

\section{Competing interests}

The authors declare that they have no competing interests.

\section{REFERENCES}

[1]. Watson R. (1998). Change in the Symbolic Meaning of Mapo Hall, 1925-1945 in G. O. Ogunremi (ed.) A Historical Cultural and Socio-Economic Study of An African City, Ibadan: Oluyole club: 84- 103.

[2]. Osasuna C.O and Ewemade F.O. (2011). Ile Timi: The Interface between Traditional and Vernacular Architecture in Ile-Ife. Structural Repairs and Maintenance of Heritage Architecture XII, 99 WIT 
Transactions on the Built Environment, 118: pp 99114. DOI: https://doi.org/10.2495/STR110091 ; Google Scholar

[3]. Adesina O.C. (1998). "Adebisi Giwa of Idikan: The Legend and Life of an Entrepreneur." In G.O.Ogunremi (ed.) A Historical Cultural and SocioEconomic Study of An African City. Ibadan: Oluyole club: 448-460. Google Scholar

[4]. Odunjo J. F. (2010). Alawiye Iwe- Kefa. Atunse Kerin. Fifth edition, Ikeja: Longman. 3: 85. Google $\underline{\text { Scholar }}$

[5]. Park E., Taffy Jones, The first Ibadan Engineer. Nigerian Field. 28: 103-114.

[6]. Ajai S. A. (1999). Bower's Tower: A Historical Monument in Ibadan. In G.O. Ogunremi (ed.) A Historical Cultural and Socio-Economic Study of an
African City. Ibadan: Oluyole Club: 69-83. Google $\underline{\text { Scholar }}$

[7]. Home R. (2013). Of Planting and Planning: The Making of British Colonial Cities. New York: Routledge. 63. Google Scholar

[8]. Home R. (1974). The influence of colonial Government upon Nigerian urbanization. PhD Thesis, University of London. P. 181. Google Scholar

[9]. Adebisi B. on the $7^{\text {th }}$ December, 2017. 55 years old.

[10]. Vanguard (2016). Sanusi Adebisi Idikan- (1882 1838) first Ibadan notable entrepreneur and philanthropist.

https://www.vanguardngr.com/2016/o7/sanusiadebisi-idikan-1882-1838-first-ibadan-notableentrepreneur-philanthropist/
Citation: Oluwaseyi A.D., Akande A. and Akeem O.A (2018). Heritage architecture in Ibadan, Nigeria: the house of Adebisi Giwa of Idikan. J Art Arch Stud. 7 (1): 11-20.

DOI: https://dx.doi.org/10.51148/jaas.2018.2 